\title{
A STUDY ON JOB SATISFACTION AND WORK LIFE BALANCE OF WOMEN EMPLOYEES IN SELECTED ORGANISATIONS WITH SPECIAL REFERENCE TO BANGALORE CITY
}

\author{
Dr. S. Ramesh \\ Head External Communications, \\ Vignan, \\ Visakhapatnam
}

\author{
Dr. Haniefuddin Shaik \\ Director CMT, \\ Visakhapatnam
}

\author{
Dr. Shaik Shamshuddin \\ Assistant Professor, \\ GITAM Institute of Management, \\ GITAM University, \\ Visakhapatnam
}

Article DOI: https://doi.org/10.36713/epra3247

\section{ABSTRACT}

The present study aims at examining the Job Satisfaction of female executives in Visakha steel plant which is a public sector organization. To be specific the following are the objectives of the present study.The attitude towards working women seems to be that while people have no objection to availing of their talents and abilities outside the home; women are not allowed to compromise on home life. And if they do, they should be made to feel the error of their ways. In the first place, the term 'working mother' is a misnomer as mothers are working round the clock even if they don't go to an office. Job satisfaction is in regard to one's feelings or state-of-mind regarding the nature of their work. Job satisfaction can be influenced by a variety of factors, eg, the quality of one's relationship with their supervisor, the quality of the physical environment in which they work, degree of fulfillment in their work, etc. Job satisfaction describes how content an individual is with his /her job. This Research paper intends to study on Job satisfaction and Work Life Balance of women employees in selected organisations of Bangalore City. The study confines with only Bangalore City the findings and outcomes may not applicable for other parts of the country.

\section{A. INTRODUCTION}

The status of women in India has been subject to many great changes over the past millennium, women in ancient time were enjoying equal status with men in the society. Due to the promotion of equal rights by many reformers, the history of women in India has been eventful. Traditions among some communities such as sati, jauhar, and devadasi have been banned and are largely defunct in modern India. However, some cases of these practices are still found in remote parts of India. Women are able to handle modern appliances which require intelligence and training and not merely physical strength. Thus, India has now several women working as pilots, driving locomotives, buses, tractors and machinery in workshops. Modernity has resulted in a growing flexibility and changes in the gender roles of men and women. The earlier conception that man was the provider of basic necessities for family and women the child bearer and care taker of home, is no longer valid in the changing social structure and economic compulsions. The socialization process forces males and females into behavioral modes, personality characteristics, and occupational roles deemed appropriate by society. Most important, these constraints bring about system that is biased in favor of males. Men have the opportunity to 
develop their talents while women may only within a severely limited range.

The consequences are as follows:- Relative Powerlessness of Women, Limited Range of Occupations for Women, Loss of Academic Potential for Women, Lack of Respect for Women's Abilities, Low Self-esteem among Women, Trials of the Aging Women. Working women i.e., those who are in paid employment, face problems at the workplace just by virtue of their being women. Social attitude to the role of women lags much behind the law. The attitude which considers women fit for certain jobs and not others, causes prejudice in those who recruit employees. Thus women find employment easily as nurses, doctors, teachers, secretaries or on the assembly line. Even when well qualified women are available, preference is given to a male candidate of equal qualifications. A gender bias creates an obstacle at the recruitment stage itself. When it comes to remuneration, though the law proclaims equality, it is not always practiced. "Work-family balance" is a term that refers to an individual's perceptions of the degree to which $\mathrm{s} /$ he is experiencing positive relationships between work and family roles, where the relationships are viewed as compatible and at equilibrium with each other. Like a fulcrum measuring the daily shifting weights of time and energy allocation between work and family life, the term, "work-family balance," provides a metaphor to countervail the historical notion that work and family relationships can often be competing, at odds, and conflicting.

\section{B. REVIEW OF LITERATURE}

Safia Ahmad, (1975), 36 “A Study of Job Satisfaction of Women Workers In Indian Industries", in her thesis she concluded the theoretical foundations of job satisfaction can be applied to any modern industry. The findings of the study suggest that the good numbers of respondents are satisfied with the job. Surya Kumar Srivastava, (1984), 37 "Relationship between Job Satisfaction and Organizational Climate: A Comparative Study of Private and Public Sectors" in his thesis submitted to University Of Roorkee he opined the out comes of job satisfaction depends on the Organizational Climate. He further opined the outcomes of job related aspects plays a vital role in the job satisfaction of employees for the purpose of this study he has chosen Private and Public Sectors. Hodson, R. (1989), 39 “Gender Differences In Job Satisfaction". This study analyzes gender differences in job satisfaction among full-time workers. Why do women report equal or greater job satisfaction than men in spite of objectively inferior jobs? Analysis reveals few differences between men and women in the determinants of job satisfaction when considering job characteristics, family responsibilities, and personal expectations. Little support is found for theories that men and women: (1) focus on different aspects of work in arriving at a given level of job satisfaction; (2) differentially condition their job satisfaction according to the extent of their family responsibilities; and (3) employ different personal expectations in evaluating their jobs. Fields, D. L. and Blum, T. C. (1997), 43 "Employee satisfaction in work groups with different gender composition," This study investigates the relationship between the gender composition of an employee's work group and the employee's job satisfaction, using a random sample over 1600 U.S. workers. After controlling possible confounding variables, our analysis shows that the level of an employee's job satisfaction is related to the gender composition of the employee's work group, and that the relationship of these variables does not differ between male and female employees. Arunima Shrivastava and Pooja Purang, (2009), 69 "Employee Perceptions Of Job Satisfaction: Comparative Study On Indian Banks, This study used independent samples t-test and qualitative analysis to study the differences in employee attitudes. Results indicated that the means of the public and private banks were significantly different from each other. Gash, V., Mertens, A. And Gordo, L. R. (2012), ${ }^{80}$ “'The Influence Of Changing Hours Of Work On Women's Life Satisfaction" this research study tests this assumption by measuring the impact of changes in working hours on life satisfaction in two countries (the UK and Germany using the German Socio-Economic Panel and the British Household Panel Survey). Researchers found decreases in working hours bring about positive and significant improvement on well-being for women. Madhu et al. (1990) ${ }^{40}$ conducted a study on role stress: differential influences of some antecedental factors. 173 managerial personnel from steel manufacturing organization and 76 from petroleum organization participated in the study. This study attempted to compare the influence of the antecedental factors namely, personal, organizational, job, superior, leadership styles and communication factors on role conflict and role ambiguity.

\section{OBJECTIVES OF THE STUDY}

(I) To Examine and analyze the Nature of Job in Selected organisations of Bangalore City

(II) To study the Working Conditions at Selected Organisations. 
To know the Analysis of Job Satisfaction in selected Organisations of Bangalore City.

(IV) To suggest measures to make the Job Satisfaction of Women Employees in selected Organisations of Bangalore City.

\section{RESEARCH METHODOLOGY}

Research in common parlance refers to a search for knowledge. Once can also define research as a scientific and systematic search for pertinent information on a specific topic. In fact, research is an art of scientific investigation. Research is an academic activity and as such the term should be used in a technical sense. According to Clifford Woody research comprises defining and redefining problems, formulating hypothesis or suggested solutions; collecting, organising and evaluating data; making deductions and reaching conclusions; and at last carefully testing the conclusions to determine whether they fit the formulating hypothesis.

i. Tools for investigation:

Different methods are adopted for investigation of the different aspects relating to the sample, which includes primary and secondary data. The researcher has personally visited the organizations in Bangalore region and administered the schedule to the employees, and collected first hand information through personal interviews. Secondary data were also collected through various documented feedback sessions on Job Satisfaction, previous internal survey reports, the number of training programs conducted on implementation and effective Job process and percentage of participation in the process.

\section{Number Of Respondents}

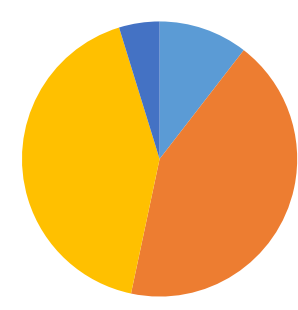

The schedule contains five-point scale and for each statement the respondents were asked to assign rating on the five-point scale as felt by them at the time of answering. The rating pattern is as follows. Several statistical tools have been applied to find out the association between the demographic variables and the four dimensions of the Job Satisfaction. In Research we have used SPSS 16.0 Version Software and Statistica 14.0 and M S Excel. Analysis was used to find out the associations between various demographic variables with the four dimensions of Job Satisfaction and the relations among the four dimensions of Job Satisfaction respectively.

ii. Reliability of the questionnaire

Cronbachs' Alpha is an internal consistency reliability analysis test, associated with scores or composite scores which can be derived using a scale or composite score. Reliability is important because in the absence of reliability it is impossible to have a validity of scale or question included in the questionnaire.

Cronbach's Alpha per dimension ( $\mathrm{s}=1, \ldots, \mathrm{p})$ :

$\alpha_{s}=m w(\lambda 1 / 2 s-1) /(\lambda 1 / 2 s(m w-1))$

Total Cronbach's Alpha is

$\alpha=\operatorname{mw}\left(\sum \mathrm{s} \lambda 1 / 2 \mathrm{~s}-1\right) / \Sigma \mathrm{s} \lambda 1 / 2 \mathrm{~s}\left(\mathrm{mw}^{-1}\right)$

With $\lambda$ s the sth diagonal element of $\Lambda$ as computed in step during the last iteration.
- JO-EO

E1-E4

E5-E6

- E7\&ABOVE
Cronbach's alpha is a measure of internal consistency that is, how closely related a set of items as a group. For conceptual purposes, the formula for the standardized Cronbach's alpha is given below.

$$
\alpha=\frac{N \cdot \bar{c}}{\bar{v}+(N-1) \cdot \bar{c}}
$$

Here $\mathrm{N}$ is equal to the number of items, c-bar is the average inter-item covariance among the items and $\mathrm{v}$-bar equals the average variance.

\section{E. LIMITATIONS}

Since the important method used in the enquiry is the case study, it has all the limitations associated with the method. The generalizations of the study cannot be expected to have universal application. Even when we try to apply to the organization of similar nature, these must be applied with caution. During the collection of information, it was found that officials were rather hesitant and ambivalent in providing the desired information and sometimes officials tolerated to discuss in some cases. This study being a case analysis of Bangalore its conclusions need not necessarily apply to all Companies or organisations of other parts of the 
EPRA International Journal of Multidisciplinary Research (IJMR) - Peer Reviewed Journal Volume: 6 | Issue: 8 | August 2020 || Journal DOI: 10.36713/epra2013 || SJIF Impact Factor: 7.032 ||ISI Value: 1.188

country. Employees were hard pressed for time in view of the job demands and rigorous work schedule. The researcher had to persuade them for sparing time for responding to the schedule and interviews. To overcome the suspicion of the executives, team leader and mangers, we took the help of the organisation's HR Department and welfare officers in establishing identity and explaining the nature and purpose of the study.

\section{F. DATA ANALYSIS}

This chapter deals with the assessment, analysis and Interpretation of Job Satisfaction Women Executives in the selected unit. The Over all mean scores of each and every item of the Job Satisfaction of Women Executives shown below

OPINIONS ON HUMAN RECOURSE POLICIES OF THE ORGANISATIONS

\begin{tabular}{|c|c|c|}
\hline S.No. & STATEMENT & MEAN \\
\hline 1 & Organizations recruitment policy is effective & 3.8904 \\
\hline 2 & Working conditions are satisfactory & 3.8952 \\
\hline 3 & Salary is up to my experience & 4.0380 \\
\hline 4 & Organizations identify the need for training regularly & 3.6142 \\
\hline 5 & Organizations conducts stress relieving counseling programs highly effective & 4.1142 \\
\hline 6 & Flexibility of work hours ensured & 3.0047 \\
\hline 7 & Opportunity to work on interesting projects is given & 3.4428 \\
\hline 8 & Management has created an open and comfortable work environment & 3.6428 \\
\hline 9 & Increments are linked to performance & 2.7380 \\
\hline 10 & Promotions are linked to targets & 2.9238 \\
\hline 11 & Performance appraisal system followed by the organization is satisfactory & 3.1761 \\
\hline 12 & Regular meetings are held in the unit for job review & 3.3571 \\
\hline 13 & Meetings are used by members to air their grievances at work & 2.9476 \\
\hline 14 & Grievances are attended immediately & 2.97619 \\
\hline 15 & There is little scope for innovation of work & 2.95714 \\
\hline 16 & $\begin{array}{l}\text { Organization sponsors our participation for the HRD. Programmers like Team } \\
\text { working Management of change, Business English, Improving communication } \\
\text { skills etc., }\end{array}$ & 4.21904 \\
\hline $\begin{array}{l}\text { Overall } \\
\text { Mean }\end{array}$ & & 3.4335 \\
\hline
\end{tabular}


EPRA International Journal of Multidisciplinary Research (IJMR) - Peer Reviewed Journal Volume: 6 | Issue: 8 | August 2020 || Journal DOI: 10.36713/epra2013 || SJIF Impact Factor: 7.032 ||ISI Value: 1.188

Overall Mean score: 3.4335, The Mean scores of all the statements stands 3.4. This reflects that a good collaboration exists in the company regarding Human Resources Policies.

\section{OPINIONS ON WORKING ENVIRONMENT OF ORGANISATIONS}

\begin{tabular}{|l|l|l|}
\hline \multicolumn{1}{|c|}{ S.No. } & \multicolumn{1}{|c|}{ STATEMENT } & MEAN \\
\hline 1. & Work environment is motivating & 3.6821 \\
\hline 2. & Female colleagues are kept out of informal discussions on dept issues & 2.2021 \\
\hline 3. & Meetings are dominated by males & 2.3222 \\
\hline 4. & Male colleagues are ready to accept work adjustments when required & 3.5076 \\
\hline 5 & The boss has reservation praising any good work done by female & 2.1878 \\
\hline 6 & Staff is not supportive to the women employees & 2.1324 \\
\hline 7. & There is a bias in the allocation of tasks in the department & 2.5553 \\
\hline 8. & Tasks with monetary benefits are given to male workers & 1.8753 \\
\hline 9. & Male colleagues underplay their female counterparts achievements & 2.0033 \\
\hline 10. & Women are not invited to participate in union activities & 1.7432 \\
\hline 11. & The job knowledge and skills of women employees are underestimated & 1.2443 \\
\hline 12. & Women are taken for granted on different issues & 1.5764 \\
\hline Mean & & $\mathbf{2 . 2 5 2 6}$ \\
\hline Overall & & \\
\hline
\end{tabular}

Overall Mean score: 2.2526, The Mean scores of all the statements stands 2.2 , This reflects that a rational working environment exists in the company

OPINIONS ON WORKING RELATION OF ORGANISATIONS

\begin{tabular}{|l|l|l|}
\hline S.No. & STATEMENT & MEAN \\
\hline 1 & Female colleagues are more understanding \& cooperative & 4.0905 \\
\hline 2 & Women have good working relations with senior colleagues & 4.3000 \\
\hline 3 & Women have good working relations with juniors colleagues & 4.1095 \\
\hline 4 & Women in higher positions are not easily approachable & 3.3190 \\
\hline 5 & There is gender bias in promotions in the industry & 2.5238 \\
\hline 6 & Gender stereotyping exist at the workplace & 2.8524 \\
\hline 7 & Women colleagues discuss gender related issues within themselves & 3.2286 \\
\hline 8 & Women have to face career based rivalry at the work place & 2.7143 \\
\hline 9 & A successful female is always alone & 2.9810 \\
\hline 10 & I consider myself a competent decision maker & 4.5048 \\
\hline 11 & People consider feminine jobs as unnecessary & 2.1857 \\
\hline 12 & Women are better in nursing, doctors, teaching not in industrial organizations & 2.0667 \\
\hline $\begin{array}{l}\text { Overall } \\
\text { Mean }\end{array}$ & & 3.2397 \\
\hline
\end{tabular}

Overall Mean score: 3.2397, The Mean scores of all the statements stands 3.2, This reflects that a good collaboration exists among employees in the company regarding working relations. 
OPINIONS ON WORK LIFE BALANCE:

\begin{tabular}{|l|l|l|}
\hline \multicolumn{1}{|c|}{ S.No. } & \multicolumn{1}{|c|}{ STATEMENT } & \multicolumn{1}{|c|}{ MEAN } \\
\hline 1 & Balancing the demands of work and personal life is more on women & 4.5762 \\
\hline 2 & My spouse's work burden increases my responsibilities at home & 2.3952 \\
\hline 3 & My head/superior is liberal in permitting me to attend my family responsibilities & 3.0810 \\
\hline 4 & I cannot spare more time for work due to my household commitments & 2.6333 \\
\hline 5 & Women have to take greater responsibility in dual career couples & 4.3667 \\
\hline 6 & I have to undertake both house and other external jobs & 4.2762 \\
\hline 7 & Women are better managers with respect to work life balance & 4.7333 \\
\hline $\begin{array}{l}\text { Overall } \\
\text { Mean }\end{array}$ & & 3.7231 \\
\hline
\end{tabular}

Overall Mean score: 3.7231, The Mean scores of all the statements stands 3.7, This reflects that employees are able to establish relationship between family and work. Analysis of Opinion of the Respondents on Four Dimensions of Job Satisfaction - Family Total Income.

\section{G. MAJOR FINDINGS}

1) Overall opinion of the respondents on the dimension of Human Recourse Policies of the Organisation has evoked a positive response.

2) Overall opinion of the respondents on the dimension of Opinion on Working Environment which suggest a rational response from respondents.

3) Overall opinions of the respondents on the said dimension of working relation in the organisation suggest women executives are having exceptional working environment.

4) It is also observed from the analysis that almost all the respondents of the total sample are positively able to manage their work family life.

5) Women are better managers with respect to work life balance.

6) also found that skills of women are not under estimated.

7) It is found from study female colleges are more understanding \& cooperative compared to male executives. It is further evident that female executives are having good understanding with superiors and subordinates.

8) Finding from analysis also suggest that women employees occupying higher positions are easily accessible.

\section{H. SUGGESTIONS}

The findings from the study indicate gaps in Job satisfaction of female executives in Selected Organisations of Bangalore City may take following initiatives to set a right path for women executives:

1. Provide a positive working environment

2. Reward and recognition
3. Involve and increase employee engagement

4. Develop the skills and potential of female executives

5. Evaluate and measure job satisfaction

6. Promotions basing on pure performance

Senior management should resist the temptation to become too personally close to their staff members. However, management should take the effort to know their employees. Management should give briefings to staff regular feedback of their performance, attitude, and value to the team and the company. Organisation should take advantage of women executives' mindset and improve operations. Maintain a training and education program for all levels of staff. If possible, create a mentoring program for newer or junior level women executives.

\section{CONCLUSION}

Investigated by several disciplines such as psychology, sociology, economics and management sciences, job satisfaction is a frequently studied subject in work and organizational literature. This is mainly due to the fact that many experts believe that job satisfaction trends can affect labour market behavior and influence work productivity, work effort, employee absenteeism and staff turnover. Moreover, job satisfaction is considered a strong predictor of overall individual well-being, as well as a good predictor of intentions or decisions of employees to leave a job. Woman is an element of source of income in modern society. The civilized pattern of life system needs the support of viable economic resources and that can be brought by more than one earning in every family. Job satisfaction may seem to be an intuitive concept that is easily understood, but the diversity of recent research on job satisfaction, also indicated in the national contributions to this comparative analytical report, still raises conceptual and methodological debates. Although this may highlight the topical interest of this issue, it also calls for further and more in-depth research into job satisfaction. 


\section{REFERENCES}

1. Kendall, D. E. (1996). Sociology in our times. Belmont: Wadsworth.

2. Arvey, R. D. (1995). Job satisfaction. In N. Nicholson (Ed.), Eppyclol2edia: Dictionary of organizational behavior. Cambridge, MA: Blackwell Publishers. pp. 272-274.

3. Spector, P. E. (1997). Job Satisfaction. Thousand Oaks, CA: Sage Publications.

4. Saleh, S. D., and Hosek, J. (1976). Job involvement: Concepts and measurements. Academy of Management Journal, pp. 213-223.

5. Hope, K. (Ed). (1972). The analysis of social mobility: Methods and approaches. Oxford: Clarendon Press.

6. Syptak, J.M., Marsland, D.W., \& Ulmer, D. (1999). Job satisfaction: Putting theory into practice. Family Practice Management.

7. Farhad Analoui, (1999) "Eight parameters of managerial effectiveness: A study of senior managers in Ghana", Journal of Management Development, Vol. 18 Iss: 4, pp.362 - 390

8. Laurence Siegel, Irving M. Lane, "Psychology in industrial organizations", R. D. Irwin, 1974. Pp. 235-289.

9. Farrell, D. (1983). Exit, voice, loyalty, and neglect as responses to job dissatisfaction: A multidimensional scaling study. Academy of Management Journal, 26(4), 596-607.

10. Safia Ahmad, (1975), "A Study of Job Satisfaction of Women Workers In Indian Industries”, Thesis submitted to University of Delhi. Pp, 194-199.

11. Bindu Gupta, (2009), "Employees' perception of workplace stressors and their attitude towards work and organisation: a study of Indian managers", International Journal of Indian Culture and Business Management, Volume 2, Number 6, pp.686-706.

12. Shalini Srivastava, (2009), "Locus of Control as a Moderator for Relationship between Organisational Role Stress and Managerial Effectiveness", the Journal of Business Perspective, vol. 13 no. 4 pp. 49-61.

13. Benjamin Artz, (2010) "Fringe benefits and job satisfaction", International Journal of Manpower, Vol. 31 Iss: 6, pp.626 - 644

14. Jacob Eskildsen, Kai Kristensen, Henrik Gjesing Antvor, (2010) "The relationship between job satisfaction and national culture", The TQM Journal, Vol. 22 Iss: 4, pp.369-378.

15. Arya P. P. Work satisfaction and its correlates. Indian Journal of Industrial Relations, 20(1), (1984).

16. Atwator, E. (Ed) (1995): "Psychology for living Adjustment Growth and Behavior Today" New Delhi Practice Hall Inc. P. 99

17. Austin, T. (2011). Relationship between nurse leader emotional intelligence and registered nurse job satisfaction. (Doctoral dissertation, The University of Texas School of Nursing at Houston). Dissertation Abstracts International, 72(11).

18. Axel R. fugl-meyer, Roland melin and Kerstin s. Meyer (2002): Life satisfaction in 18 to 64 year-old Swedes: in Relation to gender, age, partner and immigrant status Uppsala University, Sweden, 239-246.
19. C. A. Heaney; R. H. Price; J. Rafferty (1995): Increasing Coping Resources at Work: A Field Experiment to Increase Social Support, Improve Work Team Functioning, and Enhance Employee Mental Health, Journal of Organizational Behavior, Volume 16 Issue4, pages $335-352$.

20. C. Shobha Rani and M. Saradadevi (2007):" life satisfaction of married working and none working women. Prachi, journal of psycho-cultural dimensions 23(2): 153-159.

21. Caplan, R.D., cobb,S., \& French, J.R.P.(1975): "Relationships of cessation of smoking With job stress, personality and social support."Journal of Applied Psychology. 60:pp211 219.

22. Chan KB. (1977): Individual differences in reactions to stress and their personality and situational determinants: some implications for community mental health. Soc Sci Med 1977; pp89-103. 